\title{
Social Wasps (Hymenoptera: Vespidae: Polistinae) from Northeastern Brazil: State of the Art
}

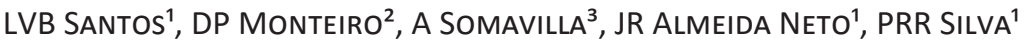 \\ 1 - Laboratório de Entomologia, Universidade Federal do Piauí - UFPI, Departamento de Fitotecnia, Centro de Ciências Agrárias, Teresina, Piauí, Brazil \\ 2 - Instituto de Ciências Biológicas, Universidade Federal do Pará, Belém, Pará, Brazil \\ 3 - Instituto Nacional de Pesquisas da Amazônia, Coordenação de Biodiversidade, Manaus, Amazonas, Brazil
}

\section{Article History}

\section{Edited by}

Sergio Andena, UEFS, Brazil

Received $\quad 02$ June 2020

Initial Acceptance 26 August 2020

Final acceptance 18 September 2020

Publication date 28 December 2020

\section{Keywords}

Bahia, Caatinga, Epiponini, Review, Semiarid.

\section{Corresponding author}

Luan Victor Brandão dos Santos

(iD) https://orcid.org/0000-0002-0301-1560

Laboratório de Entomologia

Universidade Federal do Piauí - UFPI

Departamento de Fitotecnia

Centro de Ciências Agrárias

CEP 64049-550, Teresina, Piauí, Brasil.

E-Mail: luanbrandao2@outlook.com

\begin{abstract}
For many years, research about social wasps in the Northeast was neglected due to its climatic and vegetative characteristics, insufficient incentive for training researchers to study these animals and perpetuation of low diversity of these groups in arid environments proposed by Ducke. This study carried out a bibliographic survey of research about social wasps in a 40 year period from January/1979 to December/2019, to determine the overall reality of biodiversity and richness knowledge for social wasps species. One hundred and twenty-four (124) social wasp species have been registered in the Northeast Region, distributed among 20 genera. Epiponini stands out with 84 species, followed by Mischocyttarini (24) and Polistini (16). Sergipe is the only state with no studies and records of species thus far. Such results show the importance of continuing taxonomic studies of these insects to expand their geographic distribution and to determine areas for environmental preservation in the Northeastern biomes, i.e., the Caatinga sensu lato, Cerrado and Amazon rainforest and their transition zones, as they have been insufficiently studied and present high potential for new discoveries. We suggest Alagoas, Ceará, Pernambuco and, especially Sergipe as priority areas since there is a lacking data in these states. Finally, we recommend continuing research on species reports in states like Bahia, using the map created herein to choose future study areas.
\end{abstract}

\section{Introduction}

The Northeast region of Brazil occupies $18.27 \%$ of the country's territory, covering 1,558,000 $\mathrm{km}^{2}$, and is divided into nine states: Alagoas, Bahia, Ceará, Maranhão, Paraíba, Pernambuco, Piauí, Rio Grande do Norte and Sergipe. The region presents phytophysiognomies from the Cerrado, Atlantic Forest, Amazon Forest and Caatinga biomes, with the latter almost exclusively found in the Northeast region where it covers more than half of its territory and mostly coincides with the Semi-Arid region. Additionally, it holds several transition zones between biomes, which are considered potential places of endemism (Vieira et al., 2017).

The Semi-Arid region is made up of Caatinga, characterized by high temperatures, low rainfall and water deficit, which is why this region was thought to be the result of anthropic degradation of forest regions such as the Atlantic
Forest and the Amazon Rainforest (Alves et al., 2009). Such perception has recently changed with the recognition of this region's high biodiversity and endemism of species, including social wasps (Oliveira et al., 2012; Andena \& Carpenter, 2014).

Polistinae wasps (Vespidae) are a group of Hymenoptera mainly characterized by social behavior, nest building and parental care until the end of the pupal stage (Carpenter \& Marques, 2001). Brazil presents the greatest biodiversity of social wasps in the world, with 346 species recorded, 104 of which are endemic (Richards, 1978; Carpenter \& Marques, 2001; Andena \& Carpenter, 2014; Barbosa et al., 2016; Hermes et al., 2015). Social wasps have important ecological functions, including pollination of some plants (Quirino \& Machado, 2001) and decomposition of organic material, as they feed on carcasses. In addition, these wasps prey on immature and adult forms of other insects, helping to naturally control agricultural pests (Prezoto \& Giannotti, 1994; Moretti et al., 2011). 
The incentive of research with social wasps in the Northeast has been neglected for many years (Andena \& Carpenter, 2014). This is due to understanding of the first works of naturalists, such as Adolpho Ducke (1907), of poor diversity compared to other biomes in Brazil due to characteristics related to the climate, low rainfall and vegetation conformation of the region predominantly covered by the Caatinga biome. However, currently this is not the reality, with data, mainly from Bahia the most sampled state in the Northeast and third most sampled in Brazil (Barbosa et al., 2016), indicate marked richness of species in the Northeast (Andena \& Carpenter, 2014).

Based on the locations where these surveys were conducted, there is a knowledge gap regarding the social wasp community in the Northeastern region, as many areas have not yet been sampled (Andena \& Carpenter, 2014; Barbosa et al., 2016). Therefore, it is not possible to determine the actual number of social wasp species in these biomes, nor the occurrence and distribution of rare or endemic species. Due to the importance of understanding local biodiversity, this study aimed to perform a bibliographic survey of research about social wasps in the Northeast to create an overview of the current knowledge about their biodiversity and richness and demonstrate which states present such information, as well as indicate regions with higher and lower sampling.

\section{Material and Methods}

We used Richards (1978) as a starting point for collecting data of social wasp species records in Brazil. After cataloging the species present in this book, we searched for scientific works in the Capes, Web of Science, Scielo, Scopus, Science Direct and Google Scholar databases using the search terms ("Vespa Social", AND "State name" AND "Vespidae"), in Portuguese and English, searching within the 40 year period from January 1979 to December 2019. At the end, data from the Taxonomic Catalog of Fauna of Brazil (CTFB) (Hermes et al., 2015) was used to create the species tables.

Results were included according to the following criteria: period of publication, approach consistent with the research and indexed in any of the databases mentioned above. For each article, we isolated the study area, year of publication, magazine used to publish the results, sampling method used, number of species identified and duration of the collections.

In order to calculate the Constancy of the species mentioned, we followed the methodology proposed by Barbosa et al. (2016) in which each publication found is used as a sample; with species present in more than $50 \%$ of the samples considered constant, those in $25 \%$ to $50 \%$ considered accessory and those in less than $25 \%$ considered accidental. We used the data from collected areas to form thematic maps in the free Qgis software, with the objective of spatially distributing the collection areas in this region and to demonstrate priority areas for new inventories.

\section{Results}

We found 26 publications from 1979 to 2019, most of which were scientific articles (61.5\%), along with Short Communications (30.8\%) and Book Chapters (7.7\%) (Table 1). A total of 124 species of social wasps distributed among 20 genera have been registered in the Northeast Region (Table 2). Epiponini stands out with 84 species, followed by Mischocyttarini (24) and Polistini (16). After Richards (1978), 53 species were added through new research, representing an increase of $74.6 \%$ in two decades of active research.

With the exception of Sergipe, all states in the Northeastern region present publications and records of social wasp fauna (Fig 1). The first study was carried out in Bahia, and over 10 years, it was the only state to present research

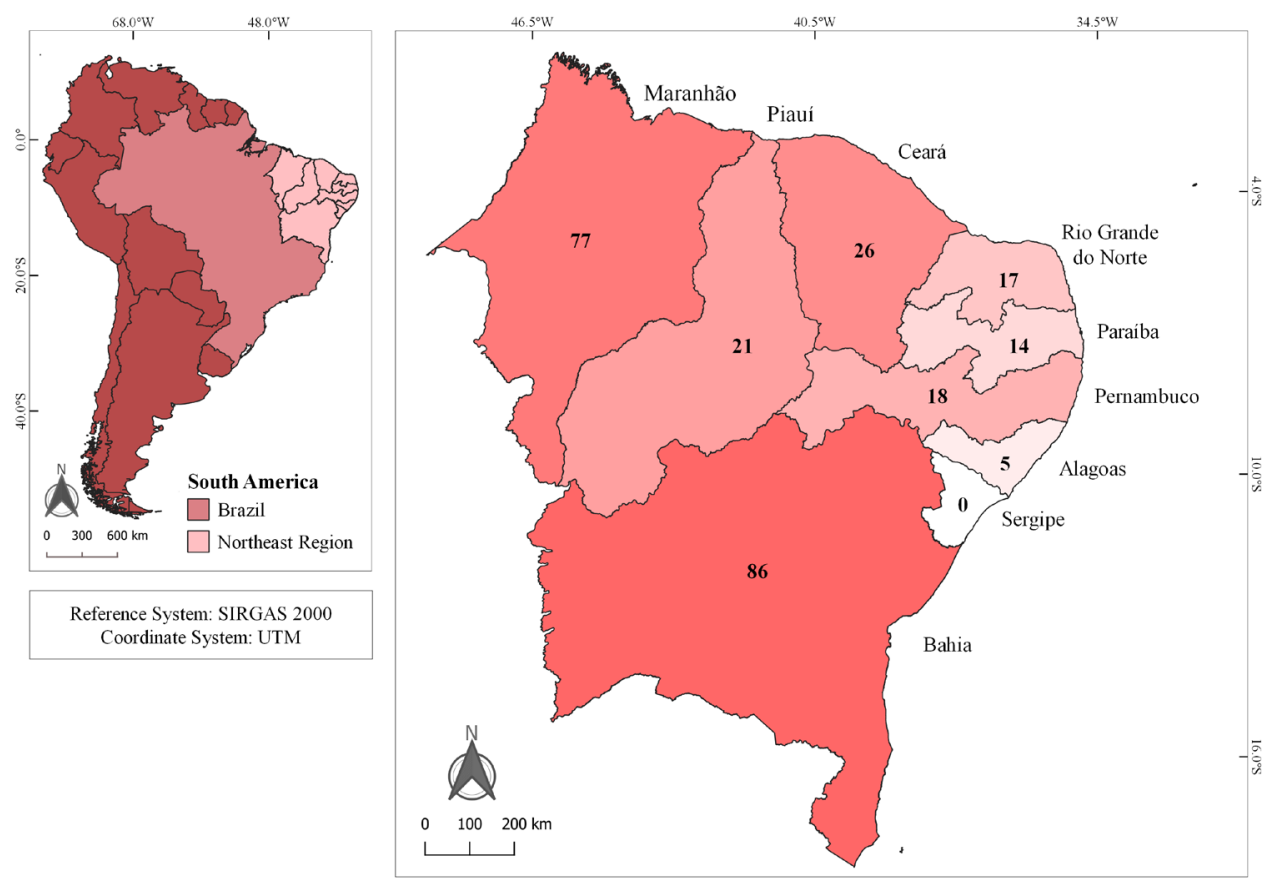

Fig 1. Distribution of social wasp species in the Northeastern states. 
Table 1. Studies of social wasps in the Northeast region of Brazil from January 1979 to December 2019. - Data not available in publication; States: AL: Alagoas; BA: Bahia; CE: Ceará; MA: Maranhão, PB: Paraíba; PE: Pernambuco; PI: Piauí; RN: Rio Grande do Norte. Biomes: Agr - Agricultural System; Amz - Amazon Forest; Atl - Atlantic Forest; Atv - active collection; Caa - Caatinga; Cer - Cerrado; Man - Mangrove forest; Res - Restinga. Methods: Flw - collection in flowers; Lgt - light trap; Lqd - attractive liquid; Mls - Malaise trap; Msp - Malaise suspended trap; Nst - nest collection. *included in the biome column for easy viewing.

\begin{tabular}{|c|c|c|c|c|}
\hline Year/Author(s) & State & Biome & Collection method(s) & Duration (months) \\
\hline Raw, A. & BA & Atl & - & 1 \\
\hline \multicolumn{5}{|l|}{2005} \\
\hline Melo et al. & BA & Cer & Atv & 8 \\
\hline \multicolumn{5}{|l|}{2006} \\
\hline Silva-Pereira \& Santos & BA & Cer & Flw & 7 \\
\hline \multicolumn{5}{|l|}{2007} \\
\hline Santos et al. (a) & BA & Atl (Man*; Res*) & Atv & 36 \\
\hline Santos et al. (b) & $\mathrm{BA}$ & Caa & Atv & 9 \\
\hline \multicolumn{5}{|l|}{2010} \\
\hline Menezes et al. & $\mathrm{BA}$ & Atl & Atv & - \\
\hline \multicolumn{5}{|l|}{2011} \\
\hline Menezes et al. & $\mathrm{BA}$ & Atl & - & - \\
\hline Silva Neto \& Andena & $\mathrm{BA}$ & Atl & - & - \\
\hline Andena \& Carpenter & MA & - & - & - \\
\hline Silva et al. & MA & Cer & Nst & 13 \\
\hline \multicolumn{5}{|l|}{2014} \\
\hline Somavilla et al. & MA & Amz & Nst; Mls; Msp; Lgt; Lqd & 9 \\
\hline \multicolumn{5}{|l|}{2016} \\
\hline Aragão \& Andena & BA & Atl & Atv; Lgt; Mls & 12 \\
\hline Virgínio et al. & $\mathrm{RN}$ & Atl & Nst & 11 \\
\hline \multicolumn{5}{|l|}{2017} \\
\hline Lopes \& Menezes & $\mathrm{BA} ; \mathrm{PE}$ & Atl & - & - \\
\hline Somavilla et al. & CE; PI & $\mathrm{Caa}$ & Atv; Nst; Mls; Msp; Lgt & 2 \\
\hline Elisei et al. & $\mathrm{PB}$ & $\mathrm{Caa}$ & Atv; Lqd & 24 \\
\hline \multicolumn{5}{|l|}{2018} \\
\hline Barbosa et al. & $\mathrm{AL}$ & Atl & Atv & - \\
\hline Virgínio et al. & $\mathrm{RN}$ & - & - & 4 \\
\hline
\end{tabular}

about social wasps, accumulating nine papers up to 2010 . This state presents $61.5 \%$ of all research from the Northeast and is the most inventoried state in the region, with four times more studies than Piauí and Maranhão. In addition, it shows the greatest consistency in studies and sampled biomes.
Bahia and Maranhão have the most Polistinae records, with 85 and 77 registered species, respectively. Individually, the other states hold up to $35 \%$ of the total records found for Bahia. Alagoas has the fewest described species and Sergipe has no wasp records at all. 
During the period of active publications, i.e., starting in 2000 , there was an increasing number of publications, which remained stable over the years. In 2011 there is the most works, however, at the end of the last decade, there was an unprecedented drop until end of 2019.

The Atlantic forest and Caatinga were the most sampled biomes, with nine and eight works, respectively. The Cerrado presented five works and the Amazon had one, being the biomes with the least amount of research in the Northeastern region. Furthermore, some authors (Silva et al., 2007a; Santos et al., 2009b) highlighted specific regions that were inventoried within these biomes, i.e., restinga, mangrove and an agricultural system.

When mapping the collection areas of the works for spatial visualization of inventoried locations, non-sampled zones are noticeable in highly inventoried states such as Bahia. It is important to highlight that the Conservation Units were shown to be priorities when choosing study areas (Fig 2).

The fauna of the Caatinga is the richest among the Northeastern biomes (Table 2), holding $65 \%$ of all species found within the Northeast region. Additionally, Mischocyttarus and Polistes present their highest diversity in the Caatinga. However, some studies do not report the biome in which specimens were found and exclusively present taxonomic and phylogenetic research with species description by territory (Andena \& Carpenter, 2011; Santos Junior et al., 2015; Virgínio et al., 2018).
The collection methods employed were active collection (12 works), nest collection (8), light trap and Malaise trap (4), attractive liquid (3), suspended malaise trap (2) and collection in flowers (1). Most surveys used only one sampling method. The in situ sampling period lasted for an average of 11 months with most samplings lasting from 6 months to a year. The shortest period was 2 months and the longest was 36 months.

According to the Constancy Index, $83.2 \%$ of the total species reported were accidental, $11.2 \%$ were accessory, and only 5.6\% were constant. Brachygastra lecheguana (Latreille, 1824), Polistes canadensis (Linnaeus, 1758), Polybia ignobilis (Haliday, 1836), Polybia occidentalis (Olivier, 1792), Polybia sericea (Olivier, 1792), Protopolybia exigua (de Saussure, 1854) were the only constant species. Additionally, all the Mischocyttarus species were accidental along with the rest of Polistes.

Agelaia pallipes (Olivier, 1792), Angiopolybia pallens (Lepeletier, 1836), Apoica pallens (Fabricius, 1804), Polybia chrysothorax (Lichtenstein, 1796), P. ignobilis, P. occidentalis, P. rejecta (Fabricius, 1798), P. sericea, Polistes versicolor (Olivier, 1791), Protopolybia exigua and Synoeca surinama (Linnaeus, 1767) were the most common species collected in all biomes, with $P$. occidentalis and $P$. sericea most frequently found in the studies. Some species do not present data about the biome where they were collected and only present the sampled state.

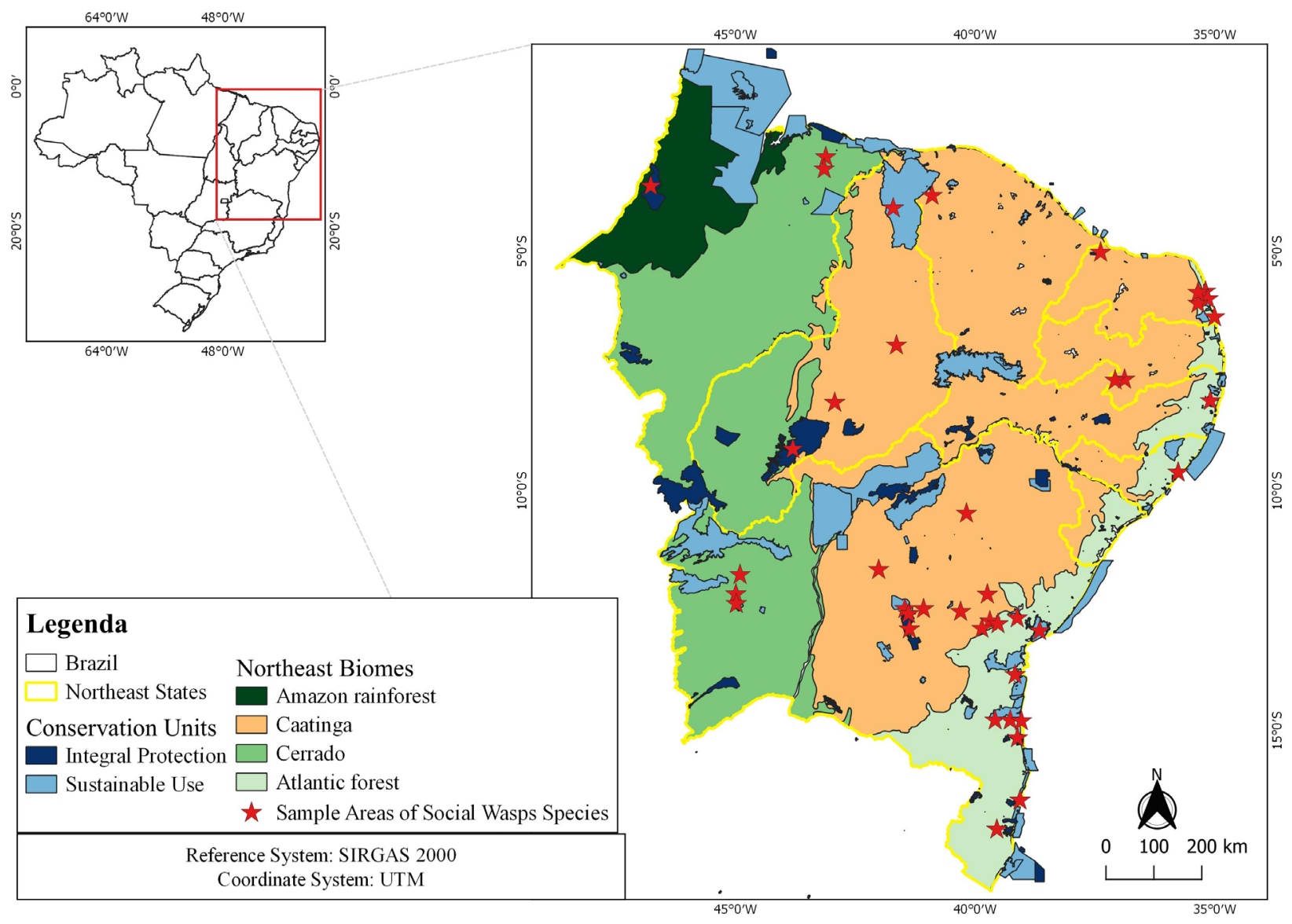

Fig 2. Areas chosen for sampling social wasps in the Northeast Region of Brazil. 
Polybia, Mischocyttarus and Polistes stand out as the most diverse genera in the Northeast, while Polybia is found in all states with records of social wasps, Mischocyttarus has not yet been recorded in Piauí and Rio Grande do Norte and is more diverse in Bahia, with $75 \%$ of registered species. The genus Polistes was most described in the Caatinga compared to the other biomes, and the Amazon Forest (2) presented less records.

\section{Discussion}

The first work to compile species described in the Northeast is by Andena and Carpenter (2014). These authors adopted the portion of the region covered by the semiarid as a study area; the research was conducted with material attached in two museums, bibliographic research and collections in two places in the state of Bahia and one in Piauí. They recorded 76 species, 70 more than Ducke's (1907) records. The states of Sergipe, Alagoas and Piauí are treat as priorities for research due to little data.

After that publication, Piauí was curiously sampled only in the portion covered by the semiarid region, reporting an addition of 17 new species (Rocha \& Silveira, 2014; Somavilla et al., 2017) to that found by Andena and Carpenter (2014). Alagoas with a survey on a fragment of Atlantic forest (Barbosa et al., 2018) and Sergipe remains as the only one without sampling.

As demonstrated by Andena and Carpenter (2014), Barbosa et al. (2016) and Somavilla et al. (2017), the Northeastern region is still poorly sampled compared to other regions of Brazil, mainly due to its climatic characteristics and low concentration of researchers, but not because it has low species diversity. By mapping the sampling areas from studies carried out in the Northeast, it was possible to determine the most inventoried areas (mainly in Bahia), as well as places that need new studies. Such biomes lacking studies include the Cerrado and the Amazon Rainforest, which is not surprising. Currently, these biomes show high deforestation due to the expansion of agriculture, population and industrial production (Silva et al. 2018). For the Amazon Rainforest region, timber extraction also occurs in the Belém Endemism Area, in Maranhão (Ricardo et al., 2017).

Conservation Units are the most frequently used areas for sampling social wasps' species in Northeast (Aragão \& Andena, 2014; Somavilla et al., 2017; Barbosa et al., 2018). Usually, researchers work in these areas due to the reduction or absence of fragmentation of the environments and anthropic pressures, as well as exclusive species, presenting unchanged or only slightly altered conditions (Gurgel et al., 2009).

The active publication period occurred along with that reported by Barbosa et al. (2016) for Brazil, with $61.5 \%$ of the papers occurring in the last 10 years, especially in 2011. Only in the last decade studies about social wasps been carried out in the other Northeastern states, increasing knowledge of social wasp fauna (Silva et al., 2011; Rocha \& Silveira, 2014; Elisei et al., 2015; Virgínio et al., 2016; Virgínio et al., 2018).
The active collection method was most frequently used in the Northeast. Such method is considered the most efficient when compared to other methods (Silveira, 2002; Jacques et al., 2018), especially for semi deciduous forests and savannas since it samples species exclusive to this method, as well as species collected in the other methods (Elpino-Campos et al., 2007; Souza et al., 2011; Elisei et al., 2017).

We did not find any standardization for the collection methods adopted in the research, especially for the passive collection methods. The methods differ regarding the duration of active collections in the field (Melo et al., 2005; Santos et al., 2006; Santos et al., 2007a; Virginio et al., 2017) and in the association of different methods (Andena \& Carpenter, 2014; Aragão \& Andena, 2016; Elisei et al., 2017; Somavilla et al., 2017). This affects the evaluation of efficiency of such methods and makes it impossible to determine which of those used in the northeast were more or less efficient in collecting wasps. There have been proposals for active collection methods associated with Malaise traps in the forest (Somavilla et al., 2014b), adoption of more efficient attractive liquids and optimization of the size and distance between traps (Maciel et al., 2016; Jacques et al., 2018); however, there have been few or have not yet been adopted in the Northeast.

The average period spent on collections was 11 months. As reported in other surveys, this period allows the analysis of seasonal changes (Elpino-Campos et al., 2007; Barbosa et al., 2016; Maciel et al., 2016), which helps analyze both seasonality and fluctuation of species throughout the year and prevents underestimation of local species (Jacques et al., 2018).

The success of Epiponini in the semiarid region is possibly due to their nesting habit by swarming and protecting their nest with an enclosure that allows greater chances of successful dispersion in search of new nesting sites and better homeothermic control when compared to the others (Andena $\&$ Carpenter, 2014). From the 19 genera of Epiponini occurring in Brazil (Carpenter \& Marques, 2001), only Nectarinella was not registered in the Northeast, it is a genus that is found in the Amazon (Silveira, \& Santos-Junior, 2016), a poorly sampled biome in the Northeast. Polistini and Mischicyttatini are tribes with independent foundation (Carpenter \& Marques, 2001) that, even having the most diverse genera, are less frequent during sampling (Silva \& Pereira, 2006; Santos et al., 2009a; Virgínio et al., 2016; Elisei et al., 2017), but also, they can be more difficult to collect depending on the method chosen for sampling (Somavilla et al., 2014a).

As seen by Barbosa et al. (2016), most of the species found (> 80\%) are accidental. Regarding the constant species, Brachygastra lecheguana, Polybia ignobilis, P. occidentalis and $P$. sericea presented the same status in the Northeast as they do throughout Brazil. The species Polistes versicolor, which is reported as constant in Brazil, is an accessory species in the Northeast, but is present in all biomes studied.

It is important to highlight a considerable increase in the records of recently described species, adding new 
occurrences and representing about one third of the national biodiversity (Richards, 1978; Carpenter \& Marques, 2001; Andena \& Carpenter, 2014; Hermes et al., 2015; Barbosa et al., 2016). Such records refute the perspectives of low diversity (Ducke, 1907) for the Northeast, especially in the Caatinga region (81 species). Thus far, this biome presents the highest species diversity on the Northeast; however, the other biomes were not as well sampled, making it impossible to affirm if it is actually the richest in the Northeast.

In Brazil, Bahia presents the most studies and reports of species in the region and is consequently more diverse. However, despite having little research compared to Bahia, Maranhão presents satisfactory diversity of species and could hold more species since much of its territory has not yet been inventoried. Additionally, it contains areas of Amazon, Cerrado, Caatinga and transition zones between these biomes that have been poorly studied.

Such results highlight the importance of continuing taxonomic studies of these insects to expand their geographic distribution and to determine areas for environmental preservation in the Northeastern biomes, i.e., Caatinga sensu lato, Cerrado and Amazon rainforest and their transition zones, as they have been insufficiently studied. We suggest primarily research in Sergipe, the only unsampled state, in the same way in Alagoas, Pernambuco, Ceará, Paraíba, Rio Grande do Norte, Piauí and Maranhão according to the number of studies carried out in each state. Furthermore, we recommend continuing research about species reports in states like Bahia, using the map created herein to choose future study areas.

\section{Acknowledgments}

We sincerely thank two anonymous referees for suggestions. To Fundação de Amparo à Pesquisa do Estado do Amazonas for the postdoctoral scholarship (FAPEAM - FIXAM, process number 062.01427/2018)) to A Somavilla.

Table 2. Species of Social Wasps registered in Northeastern Brazil. States: AL: Alagoas; BA: Bahia; CE: Ceará; MA: Maranhão, PB: Paraíba; PE: Pernambuco; PI: Piauí; RN: Rio Grande do Norte. Biomes: Atl: Atlantic Forest; Amz: Amazon Forest; Caa: Caatinga; Cer: Cerrado. Constance: Acc: Accessory; Aci: Accidental; Cons: Constant. *New species records after Richards (1978).

\begin{tabular}{|c|c|c|c|}
\hline Species & State(s) & Biome(s) & Const. \\
\hline \multicolumn{4}{|l|}{ Epiponini } \\
\hline \multicolumn{4}{|l|}{ Agelaia Lepeletier, 1836} \\
\hline Agelaia cajennensis (Fabricius, 1798) & BA; MA & Caa; Cer & Aci \\
\hline Agelaia centralis (Cameron, 1907) & $\mathrm{BA} ; \mathrm{MA}$ & Amz; Atl; Caa & Aci \\
\hline Agelaia fulvofasciata (Degeer, 1773) & MA & Amz & Aci \\
\hline Agelaia myrmecophila (Ducke, 1905) & $\mathrm{BA} ; \mathrm{MA}$ & Amz; Atl & Aci \\
\hline Agelaia pallipes (Olivier, 1792) & BA; CE; MA; PI; RN & Amz; Atl; Caa; Cer & Acc \\
\hline Agelaia testacea (Fabricius, 1804)* & MA & Amz & Aci \\
\hline Agelaia vicina (de Saussure, 1854) & $\mathrm{AL} ; \mathrm{BA} ; \mathrm{CE} ; \mathrm{MA}$ & Caa; Cer & Aci \\
\hline \multicolumn{4}{|l|}{ Apoica Lepeletier, 1836} \\
\hline Apoica arborea de Saussure, 1854 & MA & Amz & Aci \\
\hline Apoica flavissima Van der Vecht, 1973 & AL; CE; MA; PB; PI & Atl; Caa; Cer & Aci \\
\hline Apoica gelida Van der Vecht, 1973* & PE; RN & Atl; Caa & Aci \\
\hline Apoica pallens (Fabricius, 1804)* & BA; CE; MA & Amz; Atl; Caa; Cer & Aci \\
\hline Apoica pallida (Olivier, 1791) & $\mathrm{BA} ; \mathrm{CE} ; \mathrm{MA}$ & Amz; Atl; Caa; & Aci \\
\hline Apoica strigata Richards, 1978* & MA & $\mathrm{Amz}$ & Aci \\
\hline \multicolumn{4}{|l|}{ Asteloca Raw, 1985} \\
\hline Chartergellus Bequaert, 1938 & & & \\
\hline
\end{tabular}


Table 2. Species of Social Wasps registered in Northeastern Brazil. States: AL: Alagoas; BA: Bahia; CE: Ceará; MA: Maranhão, PB: Paraíba; PE: Pernambuco; PI: Piaú́; RN: Rio Grande do Norte. Biomes: Atl: Atlantic Forest; Amz: Amazon Forest; Caa: Caatinga; Cer: Cerrado. Constance: Acc: Accessory; Aci: Accidental; Cons: Constant. *New species records after Richards (1978). (Continuation)

\begin{tabular}{|c|c|c|c|}
\hline Species & State(s) & Biome(s) & Const. \\
\hline \multicolumn{4}{|l|}{ Epiponini } \\
\hline Chartergellus communis Richards, 1978 & $\mathrm{BA} ; \mathrm{CE} ; \mathrm{MA}$ & Caa; Cer & Aci \\
\hline \multicolumn{4}{|l|}{ Charterginus Fox, 1898} \\
\hline Charterginus fulvus Fox, 1898 & MA & - & Aci \\
\hline \multicolumn{4}{|l|}{ Chartergus Lepeletier, 1836} \\
\hline Chartergus globiventris de Saussure, 1854* & BA; CE; MA. PI & Caa; Cer & Aci \\
\hline \multicolumn{4}{|l|}{ Clypearia de Saussure, 1854} \\
\hline Clypearia angustior Ducke, 1906* & BA & Caa; Cer & Aci \\
\hline \multicolumn{4}{|l|}{ Epipona Latreille, 1802} \\
\hline Epipona media Cooper, 2002* & BA & Cer & Aci \\
\hline Epipona tatua (Cuvier, 1797) * & MA & Amz & Aci \\
\hline \multicolumn{4}{|l|}{ Leipomeles Möbius, 1856} \\
\hline Leipomeles dorsata (Fabricius, 1804) & BA & Atl; Caa & Aci \\
\hline \multicolumn{4}{|l|}{ Metapolybia Ducke, 1905} \\
\hline Metapolybia cingulata (Fabricius, 1804) & BA; CE; MA; PI & Atl; Caa; Cer & Acc \\
\hline Metapolybia decorata (Gribodo, 1896)* & BA & Atl & Aci \\
\hline Metapolybia docilis Richards, 1978* & $\mathrm{CE}$ & Caa & Aci \\
\hline Metapolybia miltoni Andena \& Carpenter, 2011* & MA & Cer & Aci \\
\hline Metapolybia suffusa (Fox, 1898) & BA; MA & Cer & Aci \\
\hline Metapolybia unilineata (R. von Ihering, 1904) * & MA & Cer & Aci \\
\hline \multicolumn{4}{|l|}{ Parachartergus R. von Ihering, 1904} \\
\hline Parachartergus fraternus Gribodo, 1892 & MA & Amz; Cer & Aci \\
\hline Parachartergus pseudoapicalis Willink, 1959 & BA; PE & Atl; Caa; Cer & Aci \\
\hline Parachartergus smithii (de Saussure, 1854) * & MA & Cer & Aci \\
\hline \multicolumn{4}{|l|}{ Polybia Lepeletier, 1836} \\
\hline Polybia belemensis Richards, $1970^{*}$ & BA & Caa & Aci \\
\hline Polybia bicyttarella Richards, 1951* & MA & Cer & Aci \\
\hline Polybia bistriata (Fabricius, 1804) & AL; BA; MA & Atl; Amz & Aci \\
\hline Polybia catillifex Möbius, $1856^{*}$ & BA & Atl & Aci \\
\hline Polybia chrysothorax (Lichtenstein, 1796) & BA; CE; MA; PI; RN; & Amz; Atl; Caa; Cer & Acc \\
\hline Polybia depressa (Ducke, 1905) * & MA; PI & Amz; Caa & Aci \\
\hline Polybia dimidiata (Olivier, 1792) & BA; MA & $\mathrm{Caa}$ & Aci \\
\hline Polybia dimorpha Richards, 1978* & MA & Cer & Aci \\
\hline Polybia fastidiosuscula Saussure, 1854 & BA & Caa; Atl & Aci \\
\hline Polybia flavifrons Smith, 1857 & BA; MA & Caa; Cer & Aci \\
\hline Polybia flavitincta Fox, 1898 & BA & Atl & Aci \\
\hline Polybia ignobilis (Haliday, 1836) & BA; CE; MA; PB; PE; PI; RN & Amz; Atl; Caa; Cer & Cons \\
\hline Polybia jurinei Saussure, 1854 & BA; CE; MA & Amz; Atl; Caa; Cer & Aci \\
\hline Polybia liliacea (Fabricius, 1804) & MA & Amz; Cer & Aci \\
\hline Polybia micans Ducke, 1904 & MA & $\mathrm{Amz} ; \mathrm{Caa}$ & Aci \\
\hline Polybia minarum Ducke, 1906 & BA & Caa & Aci \\
\hline Polybia occidentalis (Olivier, 1792) & BA; CE; MA; PB; PE; PI; RN & Amz; Atl; Caa; Cer & Cons \\
\hline Polybia paulista von Ihering, $1896^{*}$ & $\mathrm{BA} ; \mathrm{CE}$ & Atl; Caa; Cer & Acc \\
\hline Polybia platycephala Richards, 1951* & BA; MA & Atl; Cer & Aci \\
\hline Polybia procellosa Zavattari, 1906* & BA & Atl & Aci \\
\hline Polybia punctata Du Buysson, 1908 & BA & Atl; Caa & Aci \\
\hline
\end{tabular}


Table 2. Species of Social Wasps registered in Northeastern Brazil. States: AL: Alagoas; BA: Bahia; CE: Ceará; MA: Maranhão, PB: Paraíba; PE: Pernambuco; PI: Piauí; RN: Rio Grande do Norte. Biomes: Atl: Atlantic Forest; Amz: Amazon Forest; Caa: Caatinga; Cer: Cerrado. Constance: Acc: Accessory; Aci: Accidental; Cons: Constant. *New species records after Richards (1978). (Continuation)

\begin{tabular}{|c|c|c|c|}
\hline Species & State(s) & Biome(s) & Const. \\
\hline \multicolumn{4}{|l|}{ Epiponini } \\
\hline Polybia rejecta (Fabricius, 1798) & BA; CE; MA; PB; PI; RN & Amz; Atl; Caa; Cer & Acc \\
\hline Polybia rufitarsis Ducke, 1904* & BA & Atl & Aci \\
\hline Polybia scrobalis Richards, 1970* & MA & Amz & Aci \\
\hline Polybia sericea (Olivier, 1792) & BA; CE; MA; PB; PI; RN & Amz; Atl; Caa; Cer & Cons \\
\hline Polybia signata Ducke, 1910* & $\mathrm{BA}$ & Atl & Aci \\
\hline Polybia singularis Ducke, 1905* & MA & Amz & Aci \\
\hline Polybia striata (Fabricius, 1787) & MA & Amz & Aci \\
\hline Polybia velutina Ducke, 1905* & $\mathrm{BA}$ & - & Aci \\
\hline \multicolumn{4}{|l|}{ Protopolybia Ducke, 1905} \\
\hline Protopolybia acutiscutis (Cameron, 1906) & MA & Amz & Aci \\
\hline Protopolybia bituberculata Silveira \& Carpenter, 1995* & MA & Amz & Aci \\
\hline Protopolybia chartergoides (Gribodo, 1891)* & MA; PI & Amz; Caa; Cer & Aci \\
\hline Protopolybia dilligens (Smith, 1857)* & MA & $\mathrm{Caa}$ & Aci \\
\hline Protopolybia duckei (du Buysson, 1905)* & $\mathrm{BA}$ & $\mathrm{Caa}$ & Aci \\
\hline Protopolybia exigua (de Saussure, 1854)* & BA; CE; MA; PB; PE; PI; RN & Amz; Atl; Caa; Cer & Cons \\
\hline Protopolybia potiguara Santos, Silveira \& Carpenter 2015* & PB & $\mathrm{Caa}$ & Aci \\
\hline Protopolybia sedula (de Saussure, 1854) & $\mathrm{BA} ; \mathrm{CE} ; \mathrm{MA}$ & Atl; Caa; Cer & Aci \\
\hline Synoeca surinama (Linnaeus, 1767) & BA; MA; PB; PE; RN & Amz; Atl; Caa; Cer & Acc \\
\hline Synoeca virginea (Fabricius, 1804) & MA; PI & Amz; Caa & Aci \\
\hline \multicolumn{4}{|l|}{ Mischocyttarini } \\
\hline \multicolumn{4}{|l|}{ Mischocyttarus de Saussure, 1853} \\
\hline Mischocyttarus alfkenii (Ducke, 1904)* & $\mathrm{BA}$ & $\mathrm{Caa}$ & Aci \\
\hline Mischocyttarus bahiae Richards, 1945 & $\mathrm{BA} ; \mathrm{PE}$ & $\mathrm{Caa}$ & Aci \\
\hline Mischocyttarus bahiaensis Zikán, 1949 & $\mathrm{BA} ; \mathrm{PE}$ & $\mathrm{Caa}$ & Aci \\
\hline Mischocyttarus carbonarius de Saussure, 1854 & MA & - & Aci \\
\hline Mischocyttarus carinulatus Zikán, 1949* & BA & $\mathrm{Caa}$ & Aci \\
\hline Mischocyttarus cassununga (Ihering, 1903) & BA & Caa; Cer & Aci \\
\hline Mischocyttarus cearenses Zikán, 1945 & $\mathrm{BA} ; \mathrm{CE}$; MA & Caa; Cer & Acc \\
\hline Mischocyttarus cerberus Ducke, 1910 & $\mathrm{BA} ; \mathrm{CE} ; \mathrm{MA}$ & Caa; Cer & Acc \\
\hline Mischocyttarus drewseni Saussure, 1857 & $\mathrm{BA}$ & Caa; Cer & Aci \\
\hline Mischocyttarus efferus Silveira, 2006* & MA & - & Aci \\
\hline Mischocyttarus flavicornis Zikán, 1935 & MA & $\mathrm{Caa}$ & Aci \\
\hline Mischocyttarus imitator (Ducke, 1792)* & MA & Amz & Aci \\
\hline Mischocyttarus injucundus (de Saussure, 1854) & BA; MA & $\mathrm{Caa}$; Cer & Aci \\
\hline
\end{tabular}


Table 2. Species of Social Wasps registered in Northeastern Brazil. States: AL: Alagoas; BA: Bahia; CE: Ceará; MA: Maranhão, PB: Paraíba; PE: Pernambuco; PI: Piaú́; RN: Rio Grande do Norte. Biomes: Atl: Atlantic Forest; Amz: Amazon Forest; Caa: Caatinga; Cer: Cerrado. Constance: Acc: Accessory; Aci: Accidental; Cons: Constant. *New species records after Richards (1978). (Continuation)

\begin{tabular}{|c|c|c|c|}
\hline Species & State(s) & Biome(s) & Const. \\
\hline \multicolumn{4}{|l|}{ Mischocyttarini } \\
\hline Mischocyttarus lanei Zikán, 1949* & BA & Caa & Aci \\
\hline Mischocyttarus marginatus (Fox, 1898) * & $\mathrm{BA}$ & Caa & Aci \\
\hline Mischocyttarus montei Zikán, 1949* & $\mathrm{BA}$ & Caa & Aci \\
\hline Mischocyttarus nomurae Richards, 1978 & $\mathrm{BA} ; \mathrm{CE}$ & Caa & Aci \\
\hline Mischocyttarus punctatus Ducke, 1904 & MA & - & Aci \\
\hline Mischocyttarus rotundicollis (Cameron, 1912) & $\mathrm{AL} ; \mathrm{BA}$ & Atl; Caa & Aci \\
\hline Mischocyttarus santacruzi Raw, 2000* & BA & Atl & Aci \\
\hline Mischocyttarus surinamensis de Saussure, 1854* & $\mathrm{BA} ; \mathrm{CE} ; \mathrm{MA}$ & Caa & Aci \\
\hline Mischocyttarus timbira Silveira, 2006* & MA & Cer & Aci \\
\hline Mischocyttarus tomentosus Zikán, 1935* & BA & Atl & Aci \\
\hline \multicolumn{4}{|l|}{ Polistini } \\
\hline \multicolumn{4}{|l|}{ Polistes Latreille, 1802} \\
\hline Polistes billardieri (Fabricius, 1804) & $\mathrm{BA} ; \mathrm{PB} ; \mathrm{PE} ; \mathrm{RN}$ & Atl; Caa; Cer & Acc \\
\hline Polistes brevifissus Richards, 1978 & BA; MA; PB & Caa; Cer & Aci \\
\hline Polistes canadensis (Linnaeus, 1758) & BA; CE; MA; PB; PE; PI; RN & Atl; Caa; Cer & Cons \\
\hline Polistes carnifex (Fabricius, 1775) & $\mathrm{BA} ; \mathrm{MA} ; \mathrm{PE} ; \mathrm{RN}$ & Atl; Caa & Aci \\
\hline Polistes cinerascens de Saussure, 1854 & $\mathrm{AL} ; \mathrm{BA}$ & Atl; Caa; Cer & Aci \\
\hline Polistes ferreri de Saussure, 1853 & $\mathrm{BA}$ & Caa; Cer & Aci \\
\hline Polistes geminatus Fox, $1898^{*}$ & BA & Caa & Aci \\
\hline Polistes lanio (Fabricius, 1775) & $\mathrm{BA}$ & Caa & Aci \\
\hline Polistes melanosoma de Saussure, 1853* & $\mathrm{BA}$ & Atl & Aci \\
\hline Polistes occipitalis Ducke, 1904* & MA & - & Aci \\
\hline Polistes pacificus Fabricius, 1804 & BA; MA & Caa; $\mathrm{Cer}$ & Aci \\
\hline Polistes ridleyi Kirby, 1890 & PE (Fernando de Noronha) & - & Aci \\
\hline Polistes simillimus Zikán, 1951 & $\mathrm{BA} ; \mathrm{PB} ; \mathrm{RN}$ & Atl; Caa; Cer & Acc \\
\hline Polistes subsericeus de Saussure, 1854 & BA & Caa & Aci \\
\hline Polistes testaceicolor Bequaert, 1937* & MA & $A m z$ & Aci \\
\hline Polistes versicolor (Olivier, 1791) & BA; MA; RN & Amz; Atl; Caa; Cer & Acc \\
\hline
\end{tabular}

\section{Authors Contribution}

LVB Santos, DP Monteiro, JR Almeida Neto-

Conceptualization

LVB Santos, DP Monteiro, A Somavilla - data analysis;

LVB Santos, DP Monteiro- software;

LVB Santos, DP Monteiro, A Somavilla, JR Almeida Neto, PRR Silva - writing

\section{References}

Alves, J.J.A., Araújo, M.A. \& Nascimento, S.S. (2009). Degradação da Caatinga: uma investigação ecogeográfica. Revista Caatinga: 22: 126-135.

Andena, S.R. \& Carpenter, J.M. (2011). A new species of Metapolybia (Hymenoptera: Vespidae; Polistinae, Epiponini). Entomologica Americana, 117: 117-120. doi: 10.1664/11RA-003.1
Andena S.R. \& Carpenter J.M. (2014). Checklist das espécies de Polistinae (Hymenoptera, Vespidae) do semiárido brasileiro. In: Bravo, F. \& CalorA. (Eds). Artrópodes do Semiárido, Biodiversidade e Conservação. Printmídia, Feira de Santana, pp 169-180.

Aragão, M. \& Andena, S.R. (2016). The social wasps (Hymenoptera: Vespidae: Polistinae) of a fragment of Atlantic Forest in southern Bahia, Brazil. Journal of Natural History, 50: 1411-1426. doi: 10.1080/00222933.2015.1113317

Barbosa, B.C., Detoni, M., Maciel, T.T. \& Prezoto, F. (2016). Studies of social wasp diversity in Brazil: Over 30 years of research, advancements and priorities. Sociobiology, 63: 858880. doi: 10.13102/sociobiology.v63i3.1031

Barbosa, B.C., Marciel, T.T. \& Prezoto, F. (2018). New records of social wasps (Hymenoptera: Vespidae: Polistinae) in Alagoas state, Brazil. EntomoBrasilis, 11: 56-59. doi: 10.12741/ebrasilis.v11i1.728 
Carpenter, J.M. \& Marques, O.M. (2001). Contribuição ao estudo dos vespídeos do Brasil. Universidade Federal da Bahia, Departamento de Fitotecnia, Bahia, CD-ROM, 147p.

Ducke, A. (1907). Contribution à la connaissance de la faune hyménoptérologique du Nort-Est du Brèsil. I. Revue d' Entomologie, 26: 73-96.

Elisei, T; Albuquerque, F.A.; Andena, S.R.; Martins, C.F. (2015). New records of social wasps in the state of Paraíba, Brazil. Check List, 11: 1-3. doi: 10.15560/11.2.1600

Elisei, T., Valadares, E., Albuquerque, F.A. \& Martins, C. F. (2017). Diversity and structure of social wasps community (Hymenoptera: Vespidae, Polistinae) in neotropical dry forest. Sociobiology, 64: 111-118. doi: 10.13102/sociobiology.v64i1.1261

Elpino-Campos, Á., Del-Claro, K. \& Prezoto, F. (2007). Diversity of social wasps (Hymenoptera: Vespidae) in Cerrado fragments of Uberlândia, Minas Gerais State, Brazil. Neotropical Entomology, 36(5): 685-692. doi: 10.1590/S1519-566X2007000500008

Gilberto, M.D.M., Aguiar, C.M. \& Gobbi, N. (2006). Characterization of the social wasp guild (Hymenoptera: Vespidae) visiting flowers in the caatinga (Itatim, Bahia, Brazil). Sociobiology, 47: 1-12.

Gurgel, H.C., Hargrave, J., França, F., Holmes, R.M., Ricarte, F.M., Dias, B.F., Rodrigues, C.G.O. \& Brito, M.C.W.D. (2009). Unidades de conservação e o falso dilema entre conservação e desenvolvimento. 3: 109-119.

Hermes, M.G., Somavilla, A. \& Andena, S.R. (2015). Vespidae in Catálogo Taxonômico da Fauna do Brasil. Disponível em: $<$ http://fauna.jbrj.gov.br/fauna/faunadobrasil/4895> (Acessed date: $15 / 01 / 2020)$.

Jacques, G.C., Pires, E., Hermes, M.G., Faria, L.D.B., Souza, M.M. \& Silveira, L.C.P. (2018). Evaluating the efficiency of different sampling methods to survey social wasps (Vespidae: Polistinae) in an anthropized environment. Sociobiology, 65: 515-523. doi: 10.13102/sociobiology.v65i3.2849

Lopes, R.B. \& Menezes, R.S. (2017). Synoeca ilheensis sp. nov., a new social wasp (Hymenoptera, Vespidae, Polistinae) from Brazilian lowland Atlantic Forest. Zootaxa, 4300: 445450. doi: 10.11646 /zootaxa.4300.3.8

Maciel, T.T., Barbosa, B.C. \& Prezoto, F. (2016). Armadilhas atrativas como ferramenta de amostragem de vespas sociais (Hymenoptera: Vespidae): Uma metaanálise. EntomoBrasilis, 9: 150-157. doi: 10.12741/ebrasilis. v9i3.644

Melo, A.C., Barbosa, B.C., de Castro, M.M., de Mendonça Santos, G.M. \& Prezoto, F. (2015). The social wasp community (Hymenoptera, Vespidae) and new distribution record of Polybia ruficeps in an area of Caatinga Biome, northeastern Brazil. Checklist, 11: 1-5. doi: 10.15560/11.1.1530.
Melo, A.C., Santos, G.M.M., Cruz, J.D. \& Marques, O.M. (2005). Vespas sociais (Vespidae). In "Biodiversidade e conservação da Chapada Diamantina" Ed by Juncá, F. Funch, A. \& Rocha, W.L., Brasília: Ministério do Meio Ambiente, pp. 243-257.

Menezes, R.S., Andena, S.R., Carvalho, A.F. \& Costa, M.A. (2011). First records of Synoeca septentrionalis Richards, 1978 (Hymenoptera, Vespidae, Epiponini) in the Brazilian Atlantic Rain Forest. ZooKeys, 151: 75-78. doi: 10.3897/ zookeys.151.1882

Menezes, R.S., Carvalho Filho, A.F., Raw, A. \& Costa, M.A. (2010). Epipona media Cooper (Hymenoptera: Vespidae), a social wasp new to the Brazilian Atlantic Forest. Neotropical Entomology, 39: 1046-1047. doi: 10.1590/S1519-566X20 10000600031

Moretti, T.C., Giannotti, E., Thyssen, P.J., Solis, D.R. \& Godoy, W.A.C. (2011). Bait and habitat preferences, and temporal variability of social wasps (Hymenoptera: Vespidae) attracted to vertebrate carrion. Journal of Medical Entomology, 48: 1069-1075. doi: 10.1603/ME11068.

Oliveira, G., Araújo, M.B., Rangel, T.F., Alagador, D. \& DinizFilho, J.A.F. (2012). Conserving the Brazilian semiarid (Caatinga) biome under climate change. Biodiversity and Conservation, 21: 2913-2926. doi: 10.1007/s10531-012-0346-7.

Prezoto, F. \& Giannotti, E. (1994). Atividade forrageadora e material coletado pela vespa social Polistes similimus Zikán (1951) (Hymenoptera, Vespidae). Insecta, 3: 11-19.

Quirino, Z.G.M., \& Machado, I.C. (2001). Biologia da polinização e da reprodução de três espécies de Combretum Loefl. (Combretaceae). Brazilian Journal of Botany, 24: 181193. doi: $10.1590 / \mathrm{S} 0100-84042001000200008$

Raw, A. (2000). Mischocyttarus (Kappa) santacruzi, a new species of social wasp (Hymenoptera, Vespidae) from Eastern Brazilian wet forest. Revista Brasileira de Zoologia, 17: 941943.

Richards, O.W. (1978). The social wasps of the Americas excluding the Vespinae. London: British Museum (Natural History). $580 \mathrm{p}$.

Rocha, A.A. \& Silveira, O.T. (2014). Current knowledge about the social wasps (Hymenoptera: Vespidae) in the state of Piauí, Brazil. EntomoBrasilis, 7: 167-170. doi: 10.12741/ ebrasilis.v7i2.424

Santos Junior, J.N.D., Silveira, O.T. \& Carpenter, J. M. (2015). Phylogeny of Protopolybia Ducke, 1905 and taxonomic revision of the Protopolybia exigua species-group (Hymenoptera: Vespidae, Polistinae), with description of four new species. Zootaxa, 3956: 151-182. doi: 10.11646/ zootaxa.3956.2.1

Santos, G.M.D.M., Bichara Filho, C.C., Resende, J.J., Cruz, J.D.D. \& Marques, O.M. (2007a). Diversity and community 
structure of social wasps (Hymenoptera: Vespidae) in three ecosystems in Itaparica Island, Bahia State, Brazil. Neotropical Entomology, 36: 180-185. doi: 10.1590/S1519-566X2007 000200002

Santos, G.M., Cruz, J.D.D., Bichara Filho, C.C., Marques, O.M. \& Aguiar, C.M. (2007b). Utilização de frutos de cactos (Cactaceae) como recurso alimentar por vespas sociais (Hymenoptera, Vespidae, Polistinae) em uma área de caatinga (Ipirá, Bahia, Brasil). Revista Brasileira de Zoologia, 24: 1052-1056. doi: 10.1590/S0101-81752007000400023

Santos, G.M.D.M., Cruz, J.D., Marques, O.M. \& Gobbi, N. (2009a). Diversidade de vespas sociais (Hymenoptera: Vespidae) em áreas de cerrado na Bahia. Neotropical Entomology, 38: 317-320. doi: 10.1590/S1519-566X2009000300003

Santos, G.D.M., Bispo, P.C. \& Aguiar, C.M.L. (2009b). Fluctuations in richness and abundance of social wasps during the dry and wet seasons in three phyto-physiognomies at the tropical dry forest of Brazil. Environmental Entomology, 38: 1613-1617. doi: 10.1603/022.038.0613

Silva Neto, A.M. \& Andena, S.R. (2011). New records of Apoica pallida (Olivier, 1792) (Hymenoptera: Vespidae, Epiponini) in Bahia State. Entomobrasilis, 4: 152-153.

Silva, J.L.C., Vidal, C.A.S., Barros, L.M. \& Freitas, F.R.V. (2018). Aspectos da degradação ambiental no Nordeste do Brasil. Revista Gestão \& Sustentabilidade Ambiental, 7: 180191. doi: 10.19177/rgsa.v7e22018180-191

Silva, S.D.S., Azevedo, G.G. \& Silveira, O.T. (2011). Social wasps of two Cerrado localities in the northeast of Maranhão state, Brazil (Hymenoptera, Vespidae, Polistinae). Revista Brasileira de Entomologia, 55: 597-602. doi: 10.1590/S008556262011000400017

Silva-Pereira, V.D. \& Santos, G.M. (2006). Diversity in bee (Hymenoptera: Apoidea) and social wasp (Hymenoptera: Vespidae, Polistinae) community in" campos rupestres", Bahia, Brazil. Neotropical Entomology, 35: 165-174. doi: 10.1590/S1519-566X2006000200003

Silveira, O.T. (2002). Surveying neotropical social wasps: an evaluation of methods in the" Ferreira Penna" rnectaesearch station (ECFPn), in Caxiuanã, PA, Brazil (Hym., Vespidae,
Polistinae). Papéis Avulsos de Zoologia, 42: 299-323. doi: 10.1590/S0031-10492002001200001

Silveira, O. T. \& Santos-Junior, J.N.A.D. (2016). Nectarinella manauara, new species and record of the genus from Brazilian Amazonia (Hymenoptera, Vespidae, Polistinae). Revista Brasileira de Entomologia, 60: 238-240. doi: 10.1016/j.rbe.2016.05.001

Somavilla, A., Marques, D.W.A., Barbosa, E.A.S., Junior, J.D.S.P. \& de Oliveira, M.L. (2014a). Vespas Sociais (Vespidae: Polistinae) em uma Área de Floresta Ombrófila Densa Amazônica no Estado do Maranhão, Brasil. EntomoBrasilis, 7: 183-187. doi: 10.12741/ebrasilis.v7i3.404

Somavilla, A., Oliveira, M.L.D. \& Silveira, O.T. (2014b). Diversity and aspects of the ecology of social wasps (Vespidae, Polistinae) in Central Amazonian" terra firme" forest. Revista Brasileira de Entomologia, 58: 349-355. doi: 10.1590/s008556262014005000007

Somavilla, A., de Oliveira, M.L. \& Rafael, J.A. (2017). Social Wasps (Vespidae: Polistinae) from Two National Parks of the Caatinga Biome, in Brazil. Sociobiology, 64: 334-338. doi: 10.13102/sociobiology.v64i3.1593

Souza, A.R., Venâncio, D.F.A., Zanuncio, J.C. \& Prezoto, F. (2011). Sampling methods for assessing social wasps species diversity in a eucalyptus plantation. Journal of Economic Entomology, 104: 1120-1123. doi: 10.1603/EC11060

Vieira, L., Silva, F.A. \& Louzada, J. (2017). Escarabeíneos em uma Unidade de Conservação da Caatinga: uma floresta seca brasileira com alto valor biológico, Iheringia. Série Zoologia, 107: 1-6. doi: 10.1590/1678-4766e2017045.

Virgínio, F., Barbosa, B.C., Maciel, T.T. \& Andreazze, R. (2018). Vespas Sociais (Hymenoptera: Vespidae) da Coleção Entomológica Adalberto Antônio Varela Freire da Universidade Federal do Rio Grande do Norte, Brasil. Multiverso: Revista Eletrônica do Campus Juiz de Fora-IF Sudeste, 31: 221-226.

Virgínio, F., Maciel, T.T. \& Barbosa, B.C. (2016). Novas contribuições para o conhecimento de vespas sociais (Hymenoptera: Vespidae) para Estado do Rio Grande do Norte, Brasil. Entomotropica, 31: 221-226. 